\title{
Evaluasi Dampak Program Keluarga Harapan Terhadap Pemanfaatan Fasilitas Pelayanan Kesehatan untuk Layanan Persalinan di Indonesia (Analisis Data SUSENAS tahun 2018)
}

\section{Evaluation of the Impact of Program Keluarga Harapan on the use of health care facilities for childbirth in Indonesia (SUSENAS Data Analysis in 2018)}

\author{
Gede Wirabuana Putra ${ }^{1}$, Pujiyanto ${ }^{2}$ \\ 1)Program Magister Fakultas Kesehatan Masyarakat Universitas Indonesia \\ 2)Departemen Adminisrasi dan Kebijakan Kesehatan, Fakultas Kesehatan Masyarakat Universitas Indonesia
}

Korespondensi: Gede Wirabuana,

e-mail: buanawira09@gmail.com

\begin{abstract}
Abstrak
Program Keluarga Harapan (PKH) memiliki tujuan untuk meningkatkan taraf hidup masyarakat yang diukur melalui Indeks Pembangunan Manusia (IPM) dan Tingkat ketimpangan pengeluaran penduduk Indonesia (Gini Ratio) dengan salah satu indicator yang diakomodir adalah pemanfaatan pelayanan kesehatan. Pada tahun 2018 masih ada $16 \%$ persalinan tidak menggunakan fasilitas kesehatan. Salah satu Komponen kesehatan yang diwajibkan sebagai Keluarga Penerima manfaat (KPM) PKH adalah ibu hamil wajib bersalin di fasilitas pelayanan kesehatan. Tujuan dari penelitian ini adalah melihat pengaruh PKH terhadap pemanfaatan fasilitas kesehatan untuk bersalin di Indonesia. Metode penelitian ini adalah quasi-eksperimental degan desain cross sectional yang menggunakan data Susenas tahun 2018 dengan jumlah sampel 28.785 ibu berumur 15-49 tahun yang pernah melahirkan anak lahir hidup terakhir pada periode dua tahun sebelum survei dilaksanakan dan status ekonomi yang berada pada desil 1- 3. Analisis menggunakan metode Propensity Score Matching (PSM) dengan model Logit untuk melihat nilai OR. Hasil dari penelitian menunjukan bahwa PKH meningkatkan pemanfaatan bersalin di fasilitas kesehatan. Penerima PKH memiliki peluang 1,23 kali lebih tinggi dibandingkan dengan non-penerima PKH, setelah dilakukan kontrol pada variabel lainnya. Implementasi PKH memiliki manfaat yang cukup baik, beserta faktor pendukung dominan lainnya yaitu wilayah tempat tinggal, pendidikan, alat koumnikasi, sarana transportasi dan JKN-PBI dalam rangka membantu masyarakat terutama penduduk miskin dan rentan untuk memanfaatkan fasilitas pelayanan kesehatan untuk bersalin.

Kata Kunci : PKH, Fasilitas kesehatan, persalinan, PSM.
\end{abstract}

\begin{abstract}
Program Keluarga Harapan (PKH) aims to improve the standard of living of the people as measured through the Human Development Index (IPM) and the level of inequality in expenditure of the Indonesian population (Gini Ratio) by accommodating the utilization of health services as one of the indicator. In 2018 there are still 16\% of deliveries that were not performed by trained health workers at healthcare facilities. One health component that is required as a PKH Beneficiary Family (KPM) is that pregnant women are required to deliver in a health care facility. The purpose of this study is to look at the effect of PKH on the use of health facilities for childbirth in Indonesia. The Methods that used in this study is a quasi-experimental with cross sectional design using Susenas data in 2018 with a total sample of 28,785 mothers aged 15-49 years who had given birth to live births in the period of two years before the survey and economic status in deciles 1-3. The analysis uses the Propensity Score Matching (PSM) method with the Logit model that looks at the OR value. The Results is PKH increased maternity utilization in health facilities. PKH recipients have a 1.23 times higher chance than non-PKH recipients, after controlling for other variables. PKH implementation has quite good benefits, along with other dominant supporting factors, namely the area of residence, education, communication tools, transportation facilities and JKN-PBI in order to help the community, especially the poor and vulnerable, to utilize health care facilities for delivery.
\end{abstract}

Keywords: PKH, health facilities, delivery, PSM.

Pendahuluan

Peningkatan pembangunan bidang ekonomi serta kualitas hidup masyarakat di Indonesia memperhatikan beberapa komponen untuk mencapai Indeks Pembangunan Manusia (IPM). 
IPM memiliki tiga dimensi dasar yaitu Usia harapan hidup, tingkat pendidikan dan taraf hidup yang layak. Pada tahun 2018, Indeks Pembangunan Manusia (IPM) Indonesia mencapai 71,39 , Meningkat sebesar 0,58 poin atau tumbuh sebesar 0,82 persen dibandingkan tahun 2017. Sedangkan tingkat kesenjangan pendapatan Indonesia yang diukur dengan Gini Ratio yaitu sebesar 0,389 , sedikit membaik yaitu sebesar 0,002 poin dari pencapaian tahun 2017 (BPS, 2018). Keadaan ini didukung dengan berbagai program pemerintah, salah satunya yaitu Program Keluarga Harapan (PKH) yang dilaksanakan sejak tahun 2007 (Hidayat, 2010)

Program Keluarga Harapan (PKH) di beberapa negara dikenal dengan program Conditional cash transfers (CCT). Meksiko meluncurkan CCT (PROGRESA) pada tahun 1997. Pada bulan Maret 2002, PROGRESA mengubah namanya menjadi Oportunidades (Gertler P, 2004). Di India program CCT dikennal dengan Janani Sur-shsha Yojana (JSY) (Rahman and Pallikadavath, 2018), di filipina dengan Pantawid Pamilya (Chandury et al, 2013) di Amerika "Opportunity New York City" (ONYC) dan In Care of the People (COPE) serta SURE-P maternal and child health programme (SURE-P MCH) di Nigeria. PKH di Indonesia mengalami perkembangan cukup besar dalam kepesertaan serta manfaatnya. Mulai Juli 2007 peserta PKH terdapat di 13 provinsi dengan 720.000 rumah tangga miskin (Hidayat, 2010). Pada tahun 2018 Keluarga Penerima Manfaat (KPM) PKH mencapai 10 juta KPM PKH di Indonesia (Kementerian Sosial RI, 2018).

Manfaat CCT di Nigeria dalam 2 trimester pertama menunjukan penerima CCT pada wanita mendaftar dan menghadiri kunjungan antenatal (ANC) sebesar 93\% dibandingkan dengan tidak menerima CCT (Oduenyi, Ordu and Okoli, 2019). Jumlah perempuan hamil dalam menerima program toksoid Tetanus selama kehamilan juga mengalami peningkatan (BabaAri, Eboreime and Hossain, 2018). Penelitian sejenis di Indonesia juga menyatakan Program PKH meningkatkan pemanfaatan pelayanan kesehatan di fasilitas berbasis masyarakat (UKBM). PKH meningkatkan perawatan antenatal dan postnatal di fasilitas persalinan hingga 6,7\% (Kusuma et al., 2016). Program CCT dianggap mampu meningkatkan status kesehatan ibu tidak hanya bersalin di fasilitas kesehatan melainkan komponen lain seperti gizi ibu hamil, kunjungan ANC dan kesehatan pasca persalinan (Gertler P, 2004).

Berdasarkan data SUPAS 2015, Angka kematian ibu di Indonesia secara umum mengalami penurunan dari 390 menjadi 305 per 100.000 kelahiran hidup pada tahun 19912015.Walaupun demikian angka ini belum memenuhi target MDGs di tahun 2015 Oleh karena itu pada target SDGs, menerapkan target penurunan AKI menggunakan model Average Reduction Rate (ARR) atau yang dikenal dengan penurunan rata-rata kematian ibu sebesar 5,5\% Model menunjukkan perkiraan rata-rata penurunan AKI di Indonesia pada tahun 2030 yang diharapkan dapat menurun menjadi 131 per 100.000 kelahiran hidup (Kemenkes RI, 2019a).

Berdasarkan Riset kesehatan dasar 2018, didapatkan $16 \%$ persalinan pada perempuan umur 15- 49 tahun dilakukan tidak pada fasilitas kesehatan (Kemenkes RI, 2018)apabila dibandingkan dengan data SDKI tahun 2017 persalinan yang dilakukan tidak pada fasilitas kesehatan sebesar 21\% (SDKI, 2017). Salah satu upaya pemerintah dalam menjawab tantangan tersebut dengan cara menetapkan indikator bahwa persalinan wajib ditolong tenaga kesehatan di fasilitas pelayanan kesehatan dalam PMK no. 4 tahun 2019 dan Rencna strategis 2015-2019 (Kementrian Kesehatan RI, 2019). Salah satu sasaran KPM PKH dalam bidang kesehatan adalah Ibu hamil memiliki kewajiban bersalin di fasilitas kesehatan (Kementerian Sosial RI, 2019).Atas dasar ini peneliti tertarik mengetahui Apakah Program Keluarga Harapan memiliki dampak terhadap pemanfaatan fasilitas kesehatan untuk bersalin di Indonesia

\section{Metode Penelitian}

\section{Desain Study dan Sample}

Penelitian ini adalah quasi-eksperimental degan desain cross sectional yang menggunakan data sekunder Survei Sosial Ekonomi Nasional (Susenas) tahun 2018. Susenas 2018 mencakup 
295.155 sampel rumah tangga yang tersebar pada 34 provinsi dan 514 kabupaten/kota di Indonesia. Unit analisis dalam penelitian ini adalah Wanita Usia Subur (WUS) 15-49 tahun yang pernah melahirkan anak lahir hidup terakhir pada periode dua tahun sebelum survei dilaksanakan.kemudian kategori untuk status ekonomi yang masuk dalam inklusi yaitu desil 1 hingga desil 3. Hal ini dikarenakan kriteria KPM PKH merupakan masyarakat dengan status ekonomi miskin Dari total sampel sebanyak 1.131.825 individu yang dicacah terdapat 8.636 sampel yang sesuai dengan kriteria inklusi.

Penelitian yang bertujuan mengevaluasi sebuah program memiliki beberapa hambatan, salah satunya adalah selection bias. Selection bias dapat terjadi dikarenakan dua individu atau karakteristik yang sama memiliki peluang berbeda dalam menerima sebuah intervensi. (Rosenbaum, \& Rubin. 1984). Untuk mengatasi permasalahan tersebut, Propensity Score Matching (PSM) merupakan salah satu metode yang mampu mengatasi Selection bias. Metode PSM digunakan untuk melihat perbedaan karakteristik antara penerima PKH dan Nonpenerima PKH. kemudian PSM digunakan untuk membangun kelompok kontrol dengan mengidentifikasi berbagai kemungkinan kesamaan karakteristik melalui variabel kovariat antara kelompok kontrol dan kelompok treatment (Garrido et al., 2014) Variabel interest dalam penelitian ini adalah Program Keluarga Harapan (PKH) dan outcome yang dinilai yaitu : (Pemanfaatan fasilitas pelayanan kesehatan untuk bersalin).

Menyeimbangkan kelompok PKH dan Non-PKH dilakukan dengan melihat terlebih dahulu distribusi antar kelompok dan melihat sejauh mana data terjadi overlap berdasarkan grafik. Setelah itu variabel kovariat dilakukan penyeimbangan dengan metode kernel weighting/ kernel matching. Metode ini melakukan matching dengan cara pembobotan untuk kelompok PKH yang diberi bobot yang kemudian dibandingkan dengan kelompok NonPKH. Kernel matching dianggap mampu memaksimalkan presisi karena tetap mempertahankan ukuran sampel tanpa mengurangi sampel (Garido et al, 2014).

Uji model logit digunakan untuk mengetahui peluang PKH beserta kovariat lainnya terhadap pemanfaatan fasilitas kesehatan untuk bersalin. Model logit dilakukan dengan melakukan regress variabel interest dan beberapa variabel independen terhadap variabel dependen secara bersama-sama sebagaimana persamaan berikut :

$\frac{P i}{1-p i}=e^{\alpha+\mathrm{PKHi} \beta+X i \beta 1+X i \beta 2+\cdots+X i \beta 10}$

Persamaan (1) digunakan untuk menggambarkan analisis nilai intercept yang berasal dari variabel dummy maupun kontinu. $\mathrm{P}$ merupakan probability dari pemanfaatan fasilitas kesehatan untuk bersalin yang Dimisalkan bahwa $\mathrm{y}=1$ adalah bersalin fasilitas kesehatan dan $\mathrm{y}=0$ adalah bersalin tidak di fasilitas kesehatan. Nilai odd ratio digambarkan melalui nilai $\beta$ dari masing masing variabel dependen. Pada model logit, nilai $\mathrm{Z}$ digunakan untuk menguji signifikansi suatu koefisien secara statistik (Cameron,Trivedi, 2009).

\section{Variabel}

Variabel dependen pada penelitian ini adalah pemanfaatan fasilitas pelayanan kesehatan untuk bersalin (Rumah sakit pemerintah/swasta/RSIA, Rumah bersalin/klinik, Puskesmas, Pustu, Praktek nakes, dan Polindes/Poskesdes ) sedangkan yang tidak termasuk fasilitas pelayanan kesehatan untuk bersalin adalah (Rumah, dan lainnya)(Kemenkes RI, 2019a), kemudian PKH merupakan variabel interest dalam penelitian ini, dan varianel dependen meliputi : Wilayah Tempat tinggal (urban/rural), Status pendidikan yang dibagi menjadi dua kategori yaitu pendidikan tinggi (SMA Perguruan tinggi) dan Pendidikan rendah (tidak sekolah - SMP), Status pekerjaan (Bekerja/ tidak bekerja), Umur ibu hamil, jumlah anggota keluarga, Status ekonomi berdasarkan pengeluaran perkapita sebulan yang dibagi menjadi (miskin/ tidak miskin) dilihat berdasarkan pengeluaran perkapita lebih rendah 
dari garis kemiskinan menurut BPS (BPS, 2018a). Kepemilikkan telepon, kepemilikan HP, menggunakan Internet, Kepemiliikan sepeda motor, Kepemilikkan mobil dan JKN-PBI.

\section{Analisis Data}

Setelah menggunakan PSM dengan metode kernel weighting untuk mengatasi selection bias dilanjutkan dengan analisis multivariat dengan uji Model Logit untuk interpretasi outcome. Model logit digunakan untuk mengetahui peluang kejadian pemanfaatan bersalin di fasilitas kesehatan berdasarkan kepesertaan dalam PKH serta variabel independen lainnya dengan melihat nilai OR (Gujarati, 2008). Analisis data menggunakan aplikasi STATA versi 15.0 .

\section{Hasil}

Berdasarkan hasil deskriptif statistik yang disajikan pada tabel 1, rata-rata ibu yang berada pada desil 1-3 bersalin di fasilitas kesehatan sebesar (61\%), dari hasil tersebut didapatkan $10,8 \%$ merupkan KPM PKH Variabel independen utama (Variabel interest) pada penelitian ini adalah Program Keluarga Harapan, terlihat bahwa KPM PKH pada ibu yang melakukan persalinan dua tahun terakhir sebelum SUSENAS 2018 mencapai (18\%). Rata rata umur ibu yang bersalin adalah 32 tahun. Rata rata jumah anggota keluarga ibu bersalin yaitu 5 orang dalam satu keluarga. Ibu bersalin yang tinggal di perkotaan (Urban) sebesar $25 \%$, dari hasil tersebut didapatkan 3,5\% KPM PKH. ibu yang memiliki pekerjaan yaitu sebesar (36\%), dari hasil tersebut didapatkan 7,2\% KPM PKH . Ibu dengan Pendidikan tinggi yaitu sebesar (21\%), dari hasil tersebut didapatkan 1,7\% KPM $\mathrm{PKH}$, ibu dengan status ekonomi miskin yaitu sebesar $(53 \%)$, dari hasil tersebut didapatkan 9,7\% KPM PKH. Kepemilikan telepon sebagai alat komunikasi pada ibu sangat rendah yaitu sebesar $(0,2 \%)$, dan dari hasil tersebut tidak ada yang merupakan KPM PKH. Sedangkan untuk kepemilikan HP yaitu sebesar (43\%), dari hasil tersebut didapatkan 6,3\% KPM PKH. Ibu hamil dengan kemampuan dan memiliki akses internet yaitu sebesar (12\%), dari hasil tersebut didapatkan 1\% KPM PKH Transportasi yang dimiliki, didapatkan ibu yang memiliki sepeda motor sebesar (59\%), dari hasil tersebut didapatkan 9,7\% KPM PKH, memiliki mobil sebesar (1\%), dari hasil tersebut didapatkan 0,03\% KPM PKH dan kepemilikan perahu motor sebesar (3\%), dari hasil tersebut didapatkan 0,5\% KPM PKH. Kemudian selain $\mathrm{PKH}$, adapun program pemerintah yang mampu menjamin masyarakat miskin untuk mengakses pelayanan kesehatan, yaitu program JKN-PBI. Ibu hamil yang memiliki JKN-PBI diapatkan sebesar (62\%), dari hasil tersebut 15,2\% merupakan KPM PKH.

Tabel 1 Analisis Deskriptif $(\mathbf{N}=\mathbf{8 . 6 3 6})$

\begin{tabular}{|c|c|c|c|c|c|}
\hline \multirow{3}{*}{ Variabel } & \multirow{3}{*}{ Deskripsi } & \multirow{3}{*}{ Mean } & \multirow{3}{*}{$\begin{array}{l}\text { Std } \\
\text { Dev. }\end{array}$} & \multicolumn{2}{|c|}{ PKH } \\
\hline & & & & КРМ РКН & $\begin{array}{c}\text { Non } \\
\text { KPM } \\
\text { PKH }\end{array}$ \\
\hline & & & & (n) $\%$ & (n) $\%$ \\
\hline Faskes Bersalin & $1=$ Faskes, $0=$ Non faskes & 0,61 & 0,49 & $\begin{array}{l}(937) \\
10,8\end{array}$ & $\begin{array}{c}(4.332) \\
50,2\end{array}$ \\
\hline PKH & $\begin{array}{l}1=\text { Penerima PKH } \\
0=\text { Bukan Penerima PKH }\end{array}$ & 0,18 & 0,38 & - & - \\
\hline
\end{tabular}




\begin{tabular}{|c|c|c|c|c|c|}
\hline \multirow[b]{2}{*}{ Wilayah } & \multirow[b]{2}{*}{$1=$ Urban, $0=$ Rural } & \multirow[b]{2}{*}{0,25} & \multirow[b]{2}{*}{0,43} & (294) & \multirow{2}{*}{$\begin{array}{c}(1.848) \\
21,5\end{array}$} \\
\hline & & & & 3,5 & \\
\hline \multirow{2}{*}{ Pekerjaan } & \multirow{2}{*}{$1=$ bekerja, $0=$ Tidak Bekerja } & \multirow{2}{*}{0,36} & \multirow{2}{*}{0,48} & $(621)$ & $(2.485)$ \\
\hline & & & & 7,2 & 28,8 \\
\hline \multirow{2}{*}{ Pendidikan } & \multirow{2}{*}{$\begin{array}{l}1=\text { Pendidikan tinggi, } 0= \\
\text { Pendidikan Rendah }\end{array}$} & \multirow{2}{*}{0,21} & \multirow{2}{*}{0,41} & (146) & (1.679) \\
\hline & & & & 1,7 & 19,4 \\
\hline \multirow{2}{*}{ Status Ekonomi } & \multirow{2}{*}{$1=$ Miskin, $0=$ Tidak miskin } & \multirow{2}{*}{0,53} & \multirow{2}{*}{0,5} & (841) & (3.773) \\
\hline & & & & 9,7 & 43,6 \\
\hline Umur & $\begin{array}{l}\text { Umur Responden pada saat } \\
\text { wawancara }\end{array}$ & 31,82 & 6,18 & - & - \\
\hline $\begin{array}{l}\text { Jumlah anggota } \\
\text { keluarga }\end{array}$ & $\begin{array}{l}\text { Jumlah anggota keluarga pada saat } \\
\text { wawancara }\end{array}$ & 5,25 & 1,62 & - & - \\
\hline \multirow{2}{*}{ Aset Telpon } & \multirow{2}{*}{$1=$ Memiliki, $0=$ tidak memiliki } & \multirow{2}{*}{0,002} & \multirow{2}{*}{0,04} & (0) & (13) \\
\hline & & & & 0,0 & 0,2 \\
\hline \multirow{2}{*}{$\begin{array}{l}\text { Aset Sepeda } \\
\text { Motor }\end{array}$} & \multirow{2}{*}{$1=$ Memiliki, $0=$ tidak memiliki } & \multirow{2}{*}{0,59} & \multirow{2}{*}{0,49} & (838) & $(4.244)$ \\
\hline & & & & 9,7 & 49,3 \\
\hline \multirow{2}{*}{ Aset Perahu Motor } & \multirow{2}{*}{$1=$ Memiliki, $0=$ tidak memiliki } & \multirow{2}{*}{0,03} & \multirow{2}{*}{0,16} & (43) & (190) \\
\hline & & & & 0,5 & 2,5 \\
\hline \multirow[b]{2}{*}{ Aset Mobil } & \multirow[b]{2}{*}{$1=$ Memiliki, $0=$ tidak memiliki } & \multirow[b]{2}{*}{0,01} & \multirow[b]{2}{*}{0,1} & (3) & (87) \\
\hline & & & & 0,03 & 1,0 \\
\hline IKN PBI & 1 - Menerima 0 - tidak menerima & 062 & 040 & $(1.310)$ & $(4.042)$ \\
\hline & 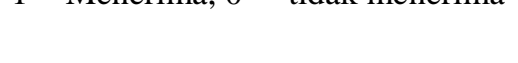 & & & 15,2 & 46,8 \\
\hline UD & 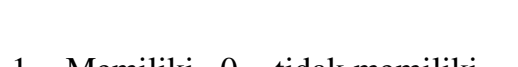 & & & (542) & $(3.202)$ \\
\hline חir & $1=$ Memilık1, $0=$ tıaаk memilık1 & 0,43 & 0,49 & 6,3 & 37,1 \\
\hline & $1=$ Menggunakan, & & & (83) & (948) \\
\hline & $0=$ tidak menggunakan & & & 1,0 & 11,0 \\
\hline
\end{tabular}

Sumber : Survei Sosial Ekonomi Nasional, 2018

Hasil deskriptif menunjukkan jumlah KPM PKH mengalami ketidaksesuaian dengan teori yang ada. Pada umumnya penerima PKH merupakan masyarakat miskin dan rentan yang berada pada desil terbawah. Berdasarkan data susenas juga menyatakan bahwa desil 1 - 3 merupakan desil dengan tingkat kesejahteraan rendah. Oleh karena itu dari hasil ini menunjukkan kejadian misstargeting pada KPM PKH. Berdasarkan hasil kajian (Togiaratua dan Badrun, 2017) yang menemukan bahwa banyak keluhan warga tentang ketepatan sasaran penerima manfaat PKH. Keadaan tersebut menunjukkan akurasi data KPM PKH perlu dilakukan perbaikan sehigga benar benar menyasar masyarakat miskin dan rentan 
Gambar 1. Distribusi Propensity Score Matching berdasarkan Penerima PKH dan Non PKH

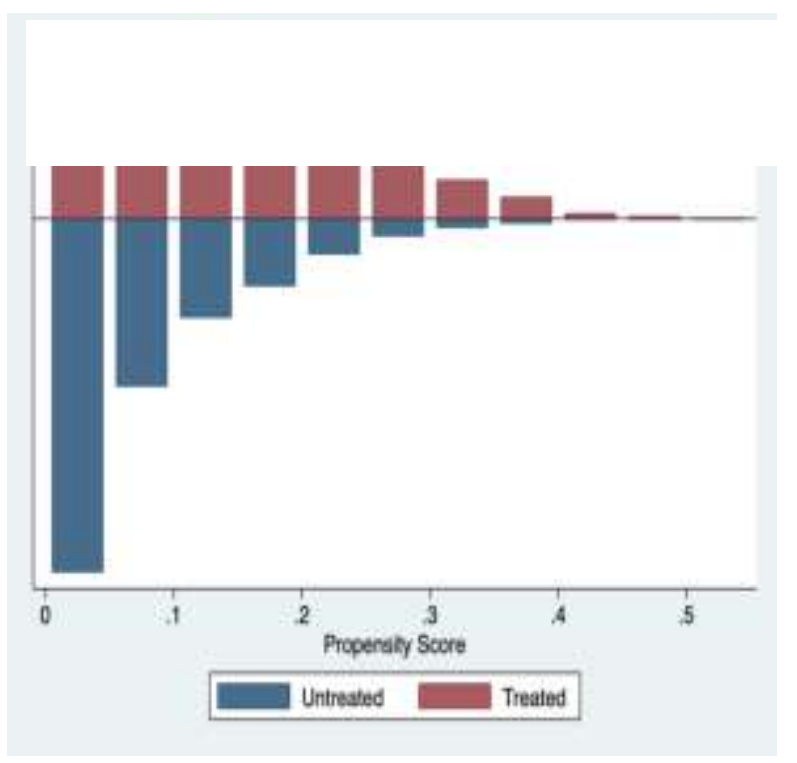

Mengatasi permasalahan misstargeting pada

KPM PKH, metode PSM digunakan untuk mengatasi seleksi bias dengan membangun dua kelompok yaitu KPM PKH dan non-KPM PKH. Kemudian dilakukan matching dengan pembobotan pada dua kelompok sesuai dengan karakterisik yang sama. Hasil dari distribusi PSM sebelum matching dijelaskan pada Gambar 1. Grafik bar menjelaskan bahwa distribusi penerima PKH dan non PKH terjadi overlap. Untuk memperkirakan dampak dari treatment, maka hasilnya diasumsikan tidak ada perbedaan antara individu yang menerima PKH dan tidak menerima PKH setelah dilakukan matching (Caliendo M, 2008). Matching dilakukan tanpa harus mengurangi sampel maka digunakan metode Kernel weight. Teknik Kernel weight pada Gambar 2 menampilkan grafik Density Plots of Mean Sebelum dan Sesudah Matching. Hasil dari grafik sesudah matching menunjukkan sudah mengalami kesamaan dan tidak terjadi overlap. Maka variabel penerima PKH dan non PKH sudah dilakukan matching (Garrido et al., 2014)

Metode PSM dilanjutkan melihat nilai Variance ratio) yang menunjukkan pembobotan
Gambar 2. Density Plots of Mean Sebelum dan Sesudah Matching

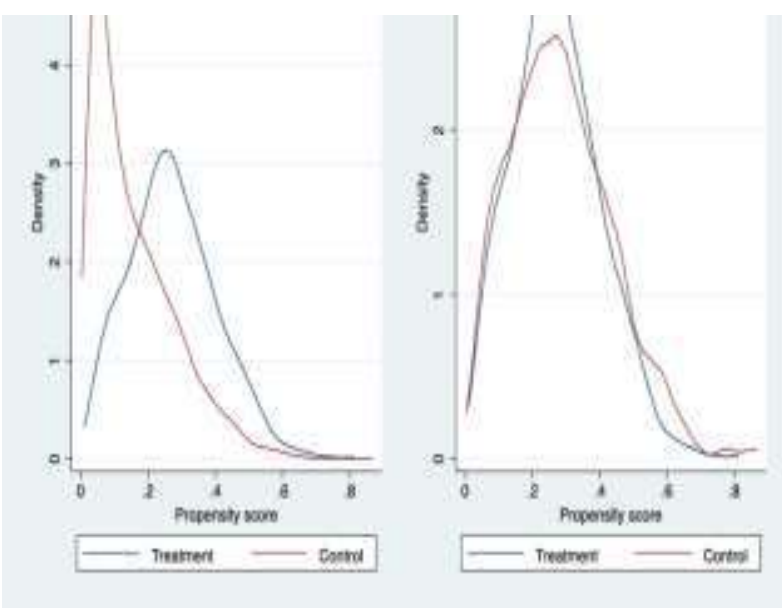

dari masing masing variabel sebelum maupun sesudah matching. Variabel dapat dikatakan balance dilihat berdasarkan Variance ratio, yang menunjukkan Propensity Score dan kovariat dari kelompok treatment dan control mendekati nilai satu sehingga dapat dikatakan balance (Rosenbaum \& Rubin, 1984). Berdasarkan nilai Variance ratio, sebagian besar variabel kovariat dapat dikatakan balance karena mendekati nilai satu. Variabel Wilayah tempat tinggal $(1,02)$, Pekerjaan $(0,99)$, Pendidikan $(1,02)$, Status Ekonomi (1,01), Aset Sepeda Motor $(0,99)$, Aset Mobil $(1,00)$, aset perahu motor $(0,90)$, kepemilikkan HP $(1,01)$, penggunaan internet $(1,02)$ dan JKN-PBI $(1,01)$. Terdapat beberapa variabel yang menunjukkan Variance ratio tidak balance yaitu Umur $(0,74)$, dan jumlah anggota keluarga $(0,48) \quad$ sedangkan variabel kepemilikkan telepon menunjukkan status omitted. tetapi variabel umur, jumlah anggota keluarga dan kepemilikkan aset telepon tetap digunakan sebagai karakteristik karena secara substansi variabel tersebut penting digunakan dalam analisis. 


\section{Hasil Uji Logit}

Tabel 2. Uji Logit Pemanfaatan Fasilitas Kesehatan untuk bersalin

\begin{tabular}{|c|c|c|}
\hline \multirow[b]{2}{*}{ Variabel } & Logit (MLE) & \multirow[b]{2}{*}{ OR } \\
\hline & $\begin{array}{c}\text { Koefisien } \\
\text { (Robust) }\end{array}$ & \\
\hline \multirow{2}{*}{ PKH } & $0.205^{* * *}$ & $1.227 * * *$ \\
\hline & $(0.066)$ & $(0.081)$ \\
\hline \multirow{2}{*}{ Wilayah } & $1.100 * * *$ & $3.006^{* * *}$ \\
\hline & $(0.066)$ & $(0.197)$ \\
\hline \multirow{2}{*}{ Pekerjaan } & $-0.333 * * *$ & $0.717 * * *$ \\
\hline & $(0.050)$ & $(0.036)$ \\
\hline \multirow{2}{*}{ Pendidikan } & $0.471 * * *$ & $1.602 * * *$ \\
\hline & $(0.067)$ & $(0.107)$ \\
\hline \multirow{2}{*}{ Status ekonomi } & $-0.278 * * *$ & $0.757 * * *$ \\
\hline & $(0.050)$ & $(0.038)$ \\
\hline \multirow{2}{*}{ Umur } & $0.028 * * *$ & $1.029 * * *$ \\
\hline & $(0.004)$ & $(0.004)$ \\
\hline \multirow{2}{*}{ Jumlah anggota keluarga } & $-0.152 * * *$ & $0.859^{* * *}$ \\
\hline & $(0.017)$ & $(0.015)$ \\
\hline \multirow{2}{*}{ Aset telpon } & 1.064 & 2.898 \\
\hline & $(0.822)$ & $(2.382)$ \\
\hline \multirow[t]{2}{*}{ HP } & $0.294 * * *$ & $1.342^{* * *}$ \\
\hline & $(0.052)$ & $(0.070)$ \\
\hline \multirow[t]{2}{*}{ Internet } & $0.496 * * *$ & $1.642 * * *$ \\
\hline & $(0.095)$ & $(0.156)$ \\
\hline
\end{tabular}


Aset sepeda motor

\begin{tabular}{lcc} 
& $(0.050)$ & $(0.092)$ \\
Aset mobil & 0.398 & 1.489 \\
& $(0.287)$ & $(0.428)$ \\
Aset perahu motor & $-0.903^{* * *}$ & $0.405^{* * *}$ \\
JKN-PBI & $(0.154)$ & $(0.062)$ \\
& $0.353^{* * *}$ & $1.423^{* * *}$ \\
Constanta & $(0.052)$ & $(0.073)$ \\
& & $0.641^{* * *}$ \\
R-squared & $-0.444 * * *$ & $(0.090)$ \\
Observations & $(0.140)$ & 0.146 \\
\hline
\end{tabular}

Robust standard errors in parentheses

$* * * \mathrm{p}<0.01, * * \mathrm{p}<0.05, * \mathrm{p}<0.1$

Setelah permasalahan selection bias diselesaikan dengan metode PSM, dan variabel covariat sudah balance selanjutnya dilakukan analisis multivariat dengan uji model logit yang melihat nilai odd ratio. Berdasarkan hasil statistk nilai signifikansi F-test diperoleh sebesar $0,00001<0,05$ yang berarti semua variabel independen secara bersama-sama berpengaruh signifikan terhadap pemanfaatan fasilitas kesehatan untuk bersalin. Hasil uji model logit berdasarkan R-squared mampu menjelaskan data pada penelitian ini sebesar 14,6\%, sedangkan sisanya dijelaskan oleh variabel lain yang tidak diteliti dalam penelitian ini. Variabel interest pada penelitian ini yaitu PKH menunjukkan hasil yang bermakna dengan nilai OR 1,23 kali terhadap pemanfaatan fasilitas kesehatan untuk bersalin dibandingkan dengan non-penerima PKH pada nilai $p$ value $<0,01$.

Variabel kovairat dalam penelitian ini yaitu wilayah tempat tinggal, pendidikan, umur, kepemilikkan HP, menggunakan internet, jumlah anggota keluarga, aset sepeda motor, dan JKN-PBI menunjukkan hasil yang bermakna dan meningkatkan peluang pemanfaatan fasilitas kesehatan untuk bersalin dengan nilai $p$ value < 0,01 . Sedangkan Variabel pekerjaan, aset perahu motor dan status ekonomi menunjukkan hasil yang bermakna dan menurunkan peluang pemanfaatan fasilitas kesehatan untuk bersalin dengan nilai $\mathrm{p}$ value $<0,01$.

\section{Pembahasan}

Program Keluarga Harapan dibentuk pada tahun 2007 di Indonesia dengan tujuan meningkatkan kualitas hidup masyarakat dengan memberikan bantuan tunai bersyarat pada rumah tangga sangat miskin dan wilayah terpencil agar mampu mengakses pelayanan kesehatan dan pendidikan tertentu(Kemensos RI, 2018). Hingga tahun 2018 sasaran tersebut sudah sesuai dengan hasil 
analisis deskriptif pada tabel 1 , menunjukkan jumlah penerima PKH sebesar $18 \%$. Kenyataanya sampai tahun 2018 jumlah keluarga penerima manfaat (KPM) PKH sudah mencapai sekitar 10 juta rumah tangga dengan status ekonomi miskin dan rentan (Kementerian Sosial RI, 2019). Secara teori masyarakat yang berada pada desil 1-3 merupakan kelompok dengan status ekonomi miskin atau tingkat kesejahteraan rendah. Jika dibandingkan dengan hasil analisis deskriptif, terdapat ketidaksesuain data KPM PKH. Masih cukup banyak masyarakat dengan status ekonomi miskin belum mendapatkan $\mathrm{PKH}$, hal ini perlu menjadi evaluasi untuk memperbaiki akurasi data KPM PKH. Apabila dilihat dari tingkat status ekonomi yang dibandingkan dengan dengan garis kemiskinan berdasarkan provinsi dan wilayah didapatkan sebesar 53\% berada di bawah garis kemiskinan. Keadaan ini menunjukkan ketidakkesesuaian dengan syarat KPM PKH. Walaupun masyarakat sudah berada pada kelompok desil 1-3 tetapi terdapat sebagian masyarakat dengan status ekonomi diatas garis kemiskinan. Sebagaimana dijelaskan bahwa $40 \%$ penduduk di Indonesia menurut Basis data terpadu 2015 (BDT 2015) tergolong rumah tangga dengan kondisi sosial-ekonomi terendah (miskin) secara nasional (TNP2K, 2017). Walaupun demikian keadaan ini dimungkinkan KPM PKH memenuhi salah satu komponen kesehatan PKH yaitu ibu hamil.

Berdasarkan hasil statistik pada tabel 3. Menunjukkan PKH memiliki pengaruh terhadap pemanfaatan fasilitas kesehatan untuk bersalin. KPM PKH memiliki peluang 1,23 kali lebih tinggi dibandingkan dengan Non-KPM PKH untuk bersalin di fasilitas kesehatan, setelah dilakukan kontrol pada variabel lainnya. Hasil ini sedikit berbeda dengan penelitian (Kusuma et al., 2016) yang menemukan pengaruh PKH terhadap pemanfaatan fasilitas kesehatan untuk bersalin hanya pada upaya kesehatan berbasis masyarakat (UKBM). Sama halnya dengan CCT di Kenya yang mampu meningkatkan pemanfaatan fasilitas kesehatan untuk bersalin (Grépin, Habyarimana and Jack, 2019). Keadaan ini menunjukkan kewajiban KPM PKH untuk bersalin di fasilitas kesehatan secara umum dapat dipenuhi dengan baik. Bantuan tunai sebesar 2,4 juta bagi ibu hamil dapat dimanfaatkan dengan baik dalam memanfaatkan fasilitas kesehatan (Kementerian Sosial RI, 2019). Upaya peningkatan pengetahuan serta pemberdayaan dilakukan melalui Kegiatan Pertemuan Peningkatan Kemampuan Keluarga (P2K2) yang wajib dilakukan tiap bulan oleh KPM PKH. Selain terbantu secara ekonomi, KPM diharapakan dapat meningkatkan pengetahuan dan perilaku terhadap kesehatan ibu hamil (Kementerian Sosial RI, 2019).

Hasil statistik menunjukkan $25 \%$ ibu yang besalin tinggal di perkotaan. Dari hasil ini menunjukkan sebagian besar ibu tinggal pada daerah pedesaan. Daerah perkotaan memiliki pengaruh bermakna terhadap pemanfaatan fasilitas kesehatan untuk bersalin. Daerah perkotaan memiliki peluang 3,01 kali lebih tinggi dibandingkan dengan daerah pedesaan untuk bersalin di fasilitas kesehatan. Ketersediaan fasilitas kesehatan dan SDM tenaga kesehatan menjadi penyebab mengapa daerah urban sangat berpangruh terhadap pemanfaat fasilitas kesehatan untuk bersalin (Kusuma et al., 2016)

Status pekerjaan memiliki pengaruh bermakna terhadap pemanfaatan fasilitas kesehatan untuk bersalin. Ibu yang memiliki pekerjaan memiliki pengaruh untuk bersalin di fasilitas kesehatan sebesar 0,717 kali dibandingkan dengan ibu yang tidak bekerja. Ibu hamil yang memiliki pekerjaan membuat ibu memiliki otonomi untuk memilih dibandingkan dengan ibu yang tidak bekerja, memilih bersalin di rumah merupakan salah satu alternative yang ada.Bersalin di fasilitas kesehatan juga dianggap memakan banyak waktu perawatan di fasilitas kesehatan. Bersalin di rumah akan menjadi alternatif yang memungkinkan ibu hamil dengan pekerjaan (Nurasih and Nurrochmi, 2017).

Jumlah anggota keluarga adalah total keseluruhan individu yang berada dalam satu lingkungan rumah maupun terdaftar dalam kartu keluarga. Dalam penelitian ini hasil statistik menunjukkan rata rata jumlah anggota keluarga 
yaitu 5 orang dalam satu keluarga. Jika dibandingkan dengan rata rata nasional hasil ini berbeda yaitu 3 orang dalam satu keluarga (BPS, 2018). Dari hasil uji statistik menunjukkan jumlah anggota keluarga memiliki pengaruh yang bermakna terhadap pemanfaatan fasilitas kesehatan untuk bersalin dengan nilai odd ratio sebesar 0,86 . Semakin bertambah jumlah keluarga setiap 1 orang menyebabkan menurunkan peluang ibu hamil bersalin di fasilitas kesehatan. $14 \%$.

Faktor ekonomi keluarga akan menjadi pertimbangan ibu hamil untuk bersalin di fasilitas kesehatan, dengan jumlah anggota keluarga yang banyak biaya hidup dan tanggungan juga menjadi lebih banyak (Togiaratua dan Badrun, 2017). Terlebih lagi biaya barang dan bahan pangan dimasing masing daerah berbeda, hal ini akan menjadi pertimbangan ibu untuk bersalin di fasilitas kesehatan. Dengan adanya bantuan sosial, khususnya PKH dalam mengatasi komponen kesehatan dan keterbatasan secara ekonomi, seharusnya ibu hamil cukup terbantu untuk mengakses pelayanan kesehatan untuk bersalin.

Walaupun PKH memberi bantuan tunai kepada ibu hamil dengan status ekonomi miskin tetapi apabila keadaan ekonomi KPM PKH tidak cenderung membaik maka akan menurunkan peluang ibu hamil bersalin di fasilitas kesehatan. Hasil statistik menunjukkan Status Ekonomi memiliki pengaruh bermakna terhadap pemanfaatan fasilitas kesehatan untuk bersalin. Ibu dengan status ekonomi miskin memiliki peluang 0,76 kali dibandingkan dengan status ekonomi tidak miskin untuk bersalin di fasilitas kesehatan. Status ekonomi miskin ditentukan berdasarkan pengeluaran perkapita yang tercatat lebih rendah dari garis kemiskinan menurut BPS (BPS, 2018). Ibu dengan status ekonomi miskin memiliki hambatan ekonomi tidak hanya pada biaya pelayanan fasilitas kesehatan untuk bersalin. Biaya non-medis seperti transportasi serta biaya opportunity cost lainnya juga menjadi pertimbangan seperti meninggalkan pekerjaan, biaya menunggu persalinan

Faktor lainnya yang mempengaruhi pemanfaatan fasilitas kesehatan untuk bersalin adalah pendidikan ibu. Hasil statistik menunjukkan pendidikan ibu memiliki pengaruh bermakna terhadap pemanfaatan fasilitas kesehatan untuk bersalin. Status pendidikan tinggi memiliki peluang 1,6 kali lebih tinggi dibandingkan dengan status pendidikan rendah untuk bersalin di fasilitas kesehatan. Pendidikan merupakan salah satu faktor yang menentukan keputusan ibu untuk bersalin di fasilitas kesehatan (Prihatin, Rahfiludin and Winarni, 2017). Dengan pendidikan yang tinggi ibu memiliki pengetahuan pentingnya bersalin di fasilitas kesehatan dan mengetahui resiko terhadap persalinan tidak di fasilitas kesehatan. Umur ibu juga menjadi pengaruh terhadap pengambilan keputusan, umur memiliki pengaruh bermakna terhadap pemanfaatan fasilitas kesehatan untuk bersalin. Secara ratarata setiap umur bertambah satu tahun, maka kemungkinan pemanfaatan fasilitas kesehatan untuk bersalin diasumsikan akan naik sebesar $2,9 \%$. Semakin bertambahnya umur, persepsi ibu terhadap resiko persalinan menjadi pertimbangan. Bersalin di fasilitas kesehatan menjadi salah satu faktor yang menurunkan resiko persalinan (Kemenkes RI, 2019a)

Kepemilikan HP pada ibu hamil memiliki pengaruh bermakna terhadap pemanfaatan fasilitas kesehatan untuk bersalin. Ibu yang memiliki HP memiliki peluang 1,34 kali lebih tinggi dibandingkan dengan ibu yang tidak memiliki HP untuk bersalin di fasilitas kesehatan.. Kepemilikan HP akan membantu mempermudah komunikasi ibu terhadap pendamping KPM PKH maupun fasilitas kesehatan terdekat dengan tempat tinggal. Selain itu kemampuan dan memiliki internet juga berpengaruh terhadap bersalin di fasilitas kesehatan. Kepemilikan dan kemampuan menggunakan internet memiliki peluang 1,64 kali lebih tinggi dibandingkan dengan ibu yang tidak memiliki internet untuk bersalin di fasilitas kesehatan. Angka pengaruh kepemilikian internet pada ibu hamil terbilang cukup tinggi. Penelitian di Kenya membuktikan pesan SMS efektif untuk mengingatkan ibu hamil dan memberikan referensi fasilitas kesehatan terdekat untuk bersalin (Grépin, Habyarimana 
and Jack, 2019).Peran aktif pendamping PKH melalui HP dan internet untuk komunikasi dan edukasi tentunya sangat membantu terhadap pendampingan KPM PKH khususnya ibu hamil.

Salah satu alat bantu pada daerah yang sulit untuk menjangkau fasilitas kesehatan adalah kepemilikan kendaraan. Kepemilikan sepeda motor dan perahu motor memiliki pengaruh bermakna terhadap pemanfaatan fasilitas kesehatan untuk bersalin. Ibu yang mempunyai sepeda motor memiliki peluang 1,83 kali lebih tinggi dibandingkan dengan ibu yang tidak mempunyai sepeda motor untuk bersalin di fasilitas kesehatan. Sedangkan Ibu yang mempunyai perahu motor memiliki peluang 0,41 kali dibandingkan dengan ibu yang tidak mempunyai perahu motor untuk bersalin di fasilitas kesehatan. Kepemilikkan perahu motor memiliki pengaruh negatif terhadap bersalin di fasilitas kesehatan. Keadaan ini dimungkinkan karena kepemilikan perahu motor biasanya dimilikki oleh profesi nelayan ataupun masyarakat yang tinggal di daerah kepulauan atau pesisir pantai. Menurut hasil kajian pada penelitian (Hendarwan H, 2015) menemukan bahwa ibu hamil di daerah kepulauan cenderung tidak bisa mengakses pelayanan kesehatan untuk bersalin dikarenakan hambatan biaya transportasi. Apabila ibu hamil tidak memiliki transportasi pribadi, maka mereka harus mengeluarkan biaya yang sangat besar untuk dapat menyewa kendaraan udara atau laut. Secara umum kepemilikan kendaraan transportasi akan meningkatkan peluang terhadap pemanfaatan fasilitas kesehatan untuk bersalin. Kepemilikan kendaraan dalam hal ini sepeda motor akan membantu ibu hamil dengan keadaan darurat untuk mempercepat menjangkau fasilitas kesehatan. Subsidi pemerintah terhadap transport juga menjadi faktor pendukung agar ibu hamil bersalin di fasilitas kesehatan. (Kusuma et al., 2016)

Jaminan Kesehatan nasional merupakan program pemerintah berupa perlindungan kesehatan agar peserta mendapat akses pelayana kesehatan dan memenuhi kebutuhan dasar kesehatan yang diberikan kepada setiap orang yang telah membayar iuran atau iurannya dibayar oleh pemerintah (Kemenhumkam, 2013). Seluruh KPM PKH merupakan penerima program JKN yang iurannya dibayar oleh pemerintah yang disebut dengan JKN-PBI. Program ini memastikan masyatakat kurang mampu untuk mendapat manfaat pelayanan kesehatan kesehatan khususnya bersalin di fasilitas kesehatan (Kemensos 2019a)

Hasil statistik menunjukkan program JKN PBI memiliki pengaruh terhadap bersalin di fasilitas kesehatan. Ibu yang terdaftar pada program JKN-PBI memiliki peluang 1,42 kali lebih tinggi dibandingkan dengan ibu yang tidak terdaftar JKN-PBI untuk bersalin di fasilitas kesehatan Sesuai dengan penelitian (Suparmi, 2019). Menunjukkan bahwa ibu yang memiliki asuransi kesehatan dalam hal ini program JKN meningkatkan peluang untuk bersalin di fasilitas kesehatan. Keadaan ini menunjukkan bahwa bagi ibu hamil dengan kondisi ekonomi miskin, jaminan kesehatan dianggap mamapu mengakomodir biaya yang timbul akibat mengakses fasilitas kesehatan untuk bersalin. biaya muncul yang akan dikeluarkan bagi ibu hamil tidak hanya pada saat mendapatkan pelayanan persalinan di fasilitas kesehatan, melainkan masih banyak biaya lainnya yang dikeluarkan yang sifatnya non-kesehatan seperti biaya transportasi, biaya waktu tunggu, maupun biaya lainnya. Dengan adanya bantuan sosial yang khusus menjamin biaya pelayanan kesehatan tentunya akan meringankan biaya yang dikeluarkan bagi ibu hamil. Program JKNPBI dapat berintegrasi terhadap PKH sehingga dapat memaksimalkan bantuan sosial yang diterima bagi ibu hamil.

Secara keseluruhan Program Keluarga Harapan merupakan program yang memberikan manfaat baik secara ekonomi,sosial, dan peningkatan pengetahuan maupun persepsi terhadap kesehatan ibu hamil. Faktor dominan dalam penelitian ini yang menunjukkan pengaruh yang cukup besar terhadap pemanfaatan fasilitas kesehatan untuk bersalin yaitu wilayah tempat tinggal ibu di perkotaan karena terkait dengan ketersediaan fasilitas kesehatan, Pendidikan ibu, Akses Komunikasi dan informasi dalah hal ini kepemilikkan HP dan 
internet, sarana transportasi yaitu sepeda motor, serta bantuan sosial komplementer JKN-PBI. Penelitian ini memiliki beberpa keterbatasan variabel pendukung lain seperti jumlah fasilitas kesehatan, jarak antara daerah tempat tinggal KPM PKH dengan fasilitas kesehatan juga perlu digambarkan sehingga mampu melihat pemerataan fasilitas kesehatan yanga ada di daerah tersebut dan tingkat jenis persalinan dan tingkat kegawatdaruratan persalinan.

\section{Kesimpulan dan Saran Kesimpulan}

PKH meningkatkan pemanfaatan bersalin di fasilitas kesehatan. Penerima PKH memiliki peluang 1,23 kali lebih tinggi dibandingkan dengan tidak menerima PKH. Implmentasi PKH memiliki manfaat dalam rangka membantu masyarakat, terutama penduduk miskin dan rentan untuk mendapat hak memanfaatkan fasilitas pelayanan kesehatan untuk bersalin, faktor pendukung lainnya seperti ketersediaan fasilitas kesehatan, alat komunikasi dan informasi, sarana transportasi serta bantuan sosial komplementer JKN-PBI harus dijadikan pertimbangan dalam evaluasi program $\mathrm{PKH}$.

\section{Saran}

Penguatan program PKH perlu dilakukan dengan meningkatkan cakupan PKH serta kualitas program PKH. Perbaikan akurasi data bagi KPM PKH menjadi kunci ketepatan sasaran program. Melakukan evaluasi data kelompok masyarakat miskin dan rentan yang belum menerima KPM PKH, kemudian melakukan pemeriksaan kembali bagi KPM dengan status ekonomi menengah keatas yang tidak sesuai sebagai KPM PKH. Evaluasi dan monitoring merupakan hal penting dalam pelaksanaan $\mathrm{PKH}$ dengan memaksimalkan peran pendamping KPM PKH untuk memberikan pengetahun mengenai persalinan di fasilitas kesehatan. Selain itu pendamping KPM PKH juga perlu memberikan rekomendasi fasilitas kesehatan terdekat bagi KPM PKH. Bantuan fasilitas berupa sarana komunikasi dan subsidi transportasi menjadi pendukung yang perlu dipertimbangkan untuk meningkatkan peluang ibu hamil memanfaatkan fasilitas kesehatan untuk bersalin.

\section{Daftar Pustaka}

Baba-Ari, F., Eboreime, E. A. and Hossain, M. (2018) 'Conditional cash transfers for maternal health interventions: Factors influencing uptake in North-Central Nigeria', International Journal of Health Policy and Management, 7(10), pp. 934942. doi: 10.15171/ijhpm.2018.56.

Badan Pusat Statistik (2015) Rata rata banyaknya anggota rumah tangga menurut provinsi di Indonesia. Jakarta. http://www.bps.go.id (diakses : 17 februari 2020).

Badan Pusat Statistik (2018) Indeks Pembangunan Manusia dan Gini Ratio di Indonesia. Jakarta. http://www.bps.go.id (diakses : 17 februari 2020).

Badan Pusat Statistik (2018a) Profil kemiskinan di Indonesia Maret 2018. Jakarta. Indonesia

Caliendo M, Kopeinig S (2008). Some Practical guidane for the implementation of propensity score matching. J Econ Surv. 2008;22(1):31-72. https ://doi.org/10.111 1/j.1467-6419.2007.00527.x.

Chaudhury, N., Friedman, J., Onishi, J.,( 2013). Philippines conditional Cash Transfer Program: Impact Evaluation 2012.

Garrido, M. M. et al. (2014) 'Methods for constructing and assessing propensity scores', Health Services Research, 49(5), pp. 1701-1720. doi: 10.1111/14756773.12182.

Gertler, P. (2004). 'Do conditional cash transfers improve child health? Evidence from PROGRESA's control randomized experiment', American Economic Review, 94 (2): 336-341

Grépin, K. A., Habyarimana, J. and Jack, W. (2019) 'Cash on delivery: Results of a randomized experiment to promote maternal health care in Kenya', Journal of Health Economics. Elsevier B.V., 65, pp. 15-30. doi: 10.1016/j.jhealeco.2018.12.001. 
Hendarwan H, Lestary H, Kawan-kawan (2015). Laporan Kajian Sistem Rujukan Maternal dan Neonatal di Provinsi papua, Maluku, NTB, dan Kalimantan Tengah. Jakarta; 2015.

Hidayat, B. (2010) 'Mengenal Rancang Bangun Program Keluarga Harapan Kesehatan', Kesmas: National Public Health Journal, 4(6), p. $243 . \quad$ doi: 10.21109/kesmas.v4i6.162.

Kemenkes RI (2018) 'Hasil Utama Riskesdas 2018'.

Kementerian Sosial RI (2018) 'PERATURAN MENTERI SOSIAL REPUBLIK INDONESIA NOMOR 1 TAHUN 2018 TENTANG PROGRAM KELUARGA HARAPAN', $P K H,(187)$.

Kementrian Kesehatan RI (2019) 'PERATURAN MENTERI KESEHATAN REPUBLIK INDONESIA NOMOR 4 TAHUN 2019 TENTANG STANDAR TEKNIS PEMENUHAN MUTU PELAYANAN DASAR PADA STANDAR PELAYANAN MINIMAL BIDANG KESEHATAN', $S P M, 4(1)$, pp. 75-84. doi: .1037//0033-2909.I26.1.78.

Kementrian kesehatan RI (2019a) Profil Kesehatan Indonesia 2018 [Indonesia Health Profile 2018]. Available at: http://www.depkes.go.id/resources/downl oad/pusdatin/profil-kesehatanindonesia/Data-dan-Informasi_ProfilKesehatan-Indonesia-2018.pdf.

Kusuma, D. et al. (2016) 'Can cash transfers improve determinants of maternal mortality? Evidence from the household and community programs in Indonesia', Social Science and Medicine. Elsevier Ltd, 163, pp. 10-20. doi: 10.1016/j.socscimed.2016.06.020.

Nurasih, N. and Nurrochmi, E. (2017) 'Analisis Alasan Memilih Bersalin Di Rumah Di Wilayah Kerja Puskesmas Sitopeng Kota Cirebon Tahun 2016', Care: Jurnal Ilmiah Ilmu Kesehatan, 5(3), p. 345. doi: 10.33366/cr.v5i3.703.

Oduenyi, C., Ordu, V. and Okoli, U. (2019) 'Assessing the operational effectiveness of a maternal and child health (MCH) conditional cash transfer pilot programme in Nigeria', BMC Pregnancy and Childbirth. BMC Pregnancy and Childbirth, 19(1), pp. 1-12. doi: 10.1186/s12884-019-2418-0.

Prihatin, T., Rahfiludin, M. and Winarni, S. (2017) 'Analisis Faktor-Faktor yang Berhubungan dengan Pemilihan Tempat Persalinan Tahun 2016 (Studi di Wilayah Puskesmas Perawatan Suban Kabupaten Tanjung Jabung Barat)', Jurnal Kesehatan Masyarakat (e-Journal), 5(3), pp. 218-225.

Rahman, M. M. and Pallikadavath, S. (2018) 'How much do conditional cash transfers increase the utilization of maternal and child health care services? New evidence from Janani Suraksha Yojana in India', Economics and Human Biology. Elsevier B.V., 31, pp. 164-183. doi: 10.1016/j.ehb.2018.08.007.

Rosenbaum, P. R., and D. R. Rubin. (1984). "Reducing Bias in Observational Studies Using Subclassification on the Propensity

Score." Journal of the American Statistical Association 79 (387): 516-24.

SDKI (2017) Badan Kependudukan dan Keluarga Berencana Nasional, Badan Pusat Statistik, \& Kementerian Kesehatan Indonesia.

Tim Nasional Percepatan Penanggulangan Kemiskinan (TNP2K) (2017) 'Basis Data Terpadu 2015: Untuk Memilah Penerima Manfaat Program Penanganan Fakir Miskin Berdasarkan Kriteria Program', (I), pp. 1-97.

Togiaratua Nainggolan dan Badrun Susantyo (2017). Upaya Percepatan Penanggulangan Kemiskinan Melalui Pogram Keluarga Harapan Studi Di Empat Daerah Di Indonesia. Pusat Penelitian dan Pengembangan Kesejahteraan Sosial, Kementerian Sosial RI 